$10.2478 /$ cer-2018-0013

\title{
MEHMED GANIĆ*
}

\section{An Empirical Analysis of Factors Affecting Bank Interest Margins: Evidence from the South East European Countries}

\begin{abstract}
This paper provides an empirical analysis of factors affecting Bank Interest Margins in eight countries of the South-East European (SEE) region between 2000 and 2014. The purpose of this paper is to examine and investigate the main drivers of Bank Interest Rate Margins across selected countries throughout the SEE region. Also, the study explored the relationship between the dependent variable Interest Rate Spread (IRS - as a proxy variable for measuring variation in Bank Interest Rate Margins) and a set of selected banks'specific variables in SEE by employing panel data estimation methodology. This research is based on aggregate data for the whole banking sector of each country. In line with some expectations, our findings confirm the importance of credit risk, bank concentration operative efficiency, and inflation expectations in determining Bank Interest Rate Margins. Interestingly, in contrast to the majority of recent empirical research, the study found an inverse relationship between the bank concentration variable and Bank Interest Rate Margins as well as between the operational efficiency variable and Bank Interest Rate Margins. Also, the study could not find statistically significant evidence that Bank Interest Rate Margins are determined by output growth, bank profitability (measured by ROA) or liquidity risk.
\end{abstract}

Keywords: bank-specific determinants, macroeconomic determinants, Interest rate spread, SEE region

JEL: $G 21, E 43$

* Associate Professor, International University of Sarajevo, Department of Management and Economics, Sarajevo, Bosnia and Herzegovina, e-mail: mganic@ius.edu.ba 


\section{Introduction}

The evolution of the financial markets in the SEE region has been very slow, and the financial sector of the SEE countries has shown itself to be underdeveloped compared to the level of development in more advanced CEE countries. As time went on, it became apparent that many countries in the SEE region increasingly found themselves attracting the interest of foreign investors from Western Europe. The growth of a number of foreign banks in the SEE region can be explained by specific underlying financial conditions. First, the Net Interest Margin (NIM) is very high, allowing banks as major financial intermediaries to adjust interest rates charged to reflect the risks exposed. On the other hand, the barriers to entry into the banking sector were set at a very low level, stimulating the entry of foreign banks into the SEE region.

The banking sector of the SEE countries is still characterized by a certain structural inefficiency and particular weaknesses, such as too high Lending-Deposit Rates Spread, and a high share of nonperforming loans (NPLs) to total loans, which has caused additional challenges for some transition countries. The point here is that the current configuration of the loan and deposit market in these countries maintains the structure of relatively high NIMs. Although the values of Lending-Deposit rates spread between the analyzed countries are different, they are significantly higher compared to the level found in the advanced countries of the EU.

One explanation offered for these trends is a lack of competition between institutional investors and alternative sources of long-term investment financing.

Although recent studies related to the factors affecting banks' NIMs are relatively extensive and varied in their findings, there is no more literature in the context of the SEE region. This study represents the first empirical research for some countries from our sample (e.g. Bosnia and Herzegovina, Albania, Serbia, and Macedonia) with very recent data.

The research aims to quantify the impact of a set of specific variables of the banking markets (including some control variables) on the variation of IRS in the SEE region by employing aggregate data (at the country level).

The empirical part of this paper refers to the empirical evidence on the influence of the banking markets' specific variables and the macroeconomic factors in measuring the movement of IRS.

One of the main contributions of this study to the existing literature about factors affecting Bank Interest Rate Margins is the focus on SEE countries that were less explored in the past (Bosnia and Herzegovina, Albania, Serbia, and Macedonia). Also, the findings of this study can be extended to other transition countries as they share many common features, such as a similar pattern of transition and their proximity to each other. 


\section{Literature review}

The bank interest rate margin has been the subject of numerous practical and some academic research. A large number of these analyses have documented a number of factors that affect the size of bank interest margin. For example, Demirgüç-Kunt and Huizinga (1999) conducted empirical research for the banking sector of 80 countries between 1988 and 1995. The research showed that differences in interest margins and bank profitability might be explained by some bank characteristics, macroeconomic conditions, explicit and implicit bank taxation, deposit insurance regulations, overall financial structure, and several underlying legal and institutional indicators. A general finding of their research shows that lower interest margins and lower profits are associated with larger bank asset to GDP ratio and lower market concentration ratio.

A pioneering study and one of the most quoted studies on the determinants of banking interest rate spread was provided by Ho and Saunders (1981). They are notable scholars who developed a model of bank margins or spreads in which a bank is viewed as a risk-averse dealer between lenders and borrowers. They employed a large data set of US commercial banks, between 1976 and 1979, to explore the relationship between an individual bank's interest margin and some bank-specific variables (i.e. implicit interest payment, the opportunity cost of required reserves, and default premium). In their model, the interest margin is seen as a premium that covers the risks associated with the maturities of transforming savings into loans. The "pure margin" is common across all banks in a single country and it depends on the degree of managerial risk aversion (i.e. the higher the risk aversion present, the higher the interest margin), the degree of bank competition (i.e. lower competition presents a higher interest rate margin), the size of transactions undertaken by the bank, market structure (i.e. the development and efficiency of financial intermediaries present a lower interest rate margin) and the variable of interest rates (i.e. higher fluctuations in interest rates present a higher interest margin due to the need to cover a larger interest rate risk).

However, NIMs of individual banks contain components that are specific to a particular bank. They depend on the interest rates paid by commercial banks on deposits, the overall quality of a loan portfolio, cost-effectiveness, and quality of management, etc.

Interest in determining NIMs increased in the 1990s (McShane and Sharpe, 1985; Allen, 1988; Carbó and Rodríguez, 2007; Angbazo, 1997; and Maudos and Solís; 2009) and much research has been done on this topic since, extending Ho and Saunder's original model of bank margins or spreads.

They extended Ho and Sunder's original model by allowing for the possibility of adding a few variables to be included into a single integrated model. The research of Maudos and Solís (2009) focuses on tested net interest income in the Mexican 
banking system. They compared 43 commercial banks by using 289 annual observations between 1993 and 2005. The results of their research suggest that the banks set higher intermediation margins if they have greater market power and lower average operating costs. More recently, Maudos and Guevara (2004) empirically analyzed the determinants of banks' interest margins, focusing on five EU countries (i.e. Germany, France, the United Kingdom, Italy and Spain) between 1993 and 2000. They employed a sample of 15,888 observations in order to examine the factors affecting the NIMs in selected banking sectors across the EU-5 countries. Also, their findings revealed that a "pure" NIM depends on the competitive conditions on the market, the current level of interest rate risk borne by banks, the average operating expenses, and degrees of risk aversion of the individual banks. They also include some other variables that are not explicitly included in the model, such as opportunity cost of reserves, payment of implicit interest and quality of management.

Agoraki (2010) empirically analyzed the determinants of the NIM at the level of the banking system of the SEE countries between 1998 and 2007. The results of her research show that NIMs at the national level are influenced by market power (e.g. a lack of competition), operational costs (i.e. high cost efficiency reduces NIMs), risk aversion, interest rate volatility, credit risk, liquidity risk, volume of loans, implicit interest payments and quality of management.

The research conducted by Dumičić and Ridzak (2013) was comprised of 152 banks from 13 countries of the CEE region (i.e. Bulgaria, Croatia, Czech Republic, Estonia, Hungary, Latvia, Lithuania, Poland, Romania, Slovak Republic and Slovenia) to measure the NIMs of individual banks. In the examination of the determinants of NIMs, their study employed some bank-specific and macroeconomic variables (i.e. GDP growth rate and inflation). They separately examined certain effects in the pre-and post-crisis period of 2008's global financial crisis. The study found that macroeconomic factors, such as capital flows, economic growth, and a seemingly sustainable fiscal policy determine the decline of margins in the pre-crisis period, while the same factors caused the reversal of margins in the post-crisis period.

Table 1. Summary of the Related Literature

\begin{tabular}{|l|l|}
\hline $\begin{array}{l}\text { Authors(s) \& Year } \\
\text { of Study }\end{array}$ & \multicolumn{1}{c|}{ Major Findings } \\
\hline $\begin{array}{l}\text { Ho and Saunders } \\
(1981)\end{array}$ & $\begin{array}{l}\text { The finding of their studies reveals that the degree of risk aversion, } \\
\text { market structure (i.e. proxy for competition), the average size of bank } \\
\text { transactions, and the variation of the interest rate on loans and deposits } \\
\text { (e.g. market risk) are by far the most important determinants explaining } \\
\text { the optimal pure spread of NIMs in the context of 80 countries over the } \\
\text { period 1988-1995. }\end{array}$ \\
\hline $\begin{array}{l}\text { McShane and Sharpe } \\
(1985)\end{array}$ & $\begin{array}{l}\text { A significant and positive impact of the capital-to-assets ratio on NIMs. } \\
\text { A negative and significant impact of the ratio "loans to total assets" } \\
\text { on the NIMs. }\end{array}$ \\
\hline
\end{tabular}




\begin{tabular}{|c|c|}
\hline $\begin{array}{c}\text { Authors(s) \& Year } \\
\text { of Study }\end{array}$ & Major Findings \\
\hline Angbazo (1997) & $\begin{array}{l}\text { NIMs are statistically significant and positively related to capital } \\
\text { to assets ratio, credit market growth, as well as default risk (as measured } \\
\text { by net loan charge-offs to total loans ratio), non-interest-bearing } \\
\text { reserves, leverage (as measured by the ratio of core capital to total } \\
\text { assets), and management efficiency (as measured by the ratio of earnings } \\
\text { to total assets). By contrast, his study found a negative and significant } \\
\text { relationship between liquidity risk (as measured by liquid to total assets) } \\
\text { and the NIM using a sample of US banks. }\end{array}$ \\
\hline $\begin{array}{l}\text { Demirgüç-Kunt and } \\
\text { Huizinga (1999) }\end{array}$ & $\begin{array}{l}\text { NIMs are positive and significantly influenced by the ratio of equity } \\
\text { to lagged total assets, by the ratio of loans to total assets, by the bank's } \\
\text { size (as measured as the log of the bank's total assets), by the ratio } \\
\text { of overhead costs to total assets, by inflation rate, and by the short-term } \\
\text { market interest rate in real terms, while output growth does not seem } \\
\text { to have any impact on the NIM. }\end{array}$ \\
\hline $\begin{array}{l}\text { Brock and Suarez } \\
(2000)\end{array}$ & $\begin{array}{l}\text { They found statistically significant evidence that some bank-specific } \\
\text { and macroeconomics variables (i.e. liquidity and capital risk at the bank } \\
\text { level, and by interest rate volatility, inflation and GDP growth) have } \\
\text { an important role in determining banks' spread levels in the context } \\
\text { of five Latin American countries (i.e. Argentina, Bolivia, Colombia, } \\
\text { Chile, and Peru). }\end{array}$ \\
\hline $\begin{array}{l}\text { Saunders and } \\
\text { Schumacher (2000) }\end{array}$ & $\begin{array}{l}\text { The authors found that bank market structure, interest rate volatility } \\
\text { and bank capitalization play an important role in the determination } \\
\text { of spreads for six selected European countries and the U.S. (during } \\
\text { the period 1988-1995 using a sample of } 614 \text { banks). They also found } \\
\text { a positive and significant relationship between non-earning assets } \\
\text { to assets ratio and the NIM. }\end{array}$ \\
\hline $\begin{array}{l}\text { Maudos and Guevara } \\
(2004)\end{array}$ & $\begin{array}{l}\text { The results obtained in their study found that NIMs were influenced } \\
\text { significantly by some bank-specific variables (i.e. credit risk, internal } \\
\text { rate of return, capital ratio to assets ratio, cost to total assets ratio, bank } \\
\text { operating costs) in Western and European Union accession countries. } \\
\text { Also, they found in their research a negative and statistically significant } \\
\text { relationship between cost to income ratio and the NIM. }\end{array}$ \\
\hline $\begin{array}{l}\text { Liebeg and } \\
\text { Schwaiger (2006) }\end{array}$ & $\begin{array}{l}\text { The authors found that the NIM depended positively on the Lerner } \\
\text { index, operating costs, risk aversion, and interest rate risk while the } \\
\text { average size of operations and the co-movement of interest rate and } \\
\text { credit risk have no significant impact on the NIM. }\end{array}$ \\
\hline $\begin{array}{l}\text { Carbó and Rodríguez } \\
\text { (2007) }\end{array}$ & $\begin{array}{l}\text { The study found statistically significant and positive impact of selected } \\
\text { bank variables on NIMs. NIMs are influenced by credit risk } \\
\text { (as measured by loan default to total loans), interest rate risk (as the } \\
\text { difference between the interbank market (three months) rate and the } \\
\text { interest rate for customer deposits), capital to assets ratio (as measured } \\
\text { by capital and reserves to total assets) while HHI does not appear } \\
\text { to be significantly related to the NIM. }\end{array}$ \\
\hline $\begin{array}{l}\text { Claeys and Vennet } \\
\text { (2008) }\end{array}$ & $\begin{array}{l}\text { The study concludes that NIMs are affected by concentration, } \\
\text { operational efficiency, capital adequacy and risk behavior in the case } \\
\text { of Western and Central-Eastern European countries (from } 1994 \text { to } 2001 \text {, } \\
\text { employing a sample of } 2279 \text { banks from } 36 \text { countries) }\end{array}$ \\
\hline
\end{tabular}


Mehmed Ganić

\begin{tabular}{|l|l|}
\hline $\begin{array}{c}\text { Authors(s) \& Year } \\
\text { of Study }\end{array}$ & \multicolumn{1}{c|}{ Major Findings } \\
\hline $\begin{array}{l}\text { Maudos and Solís } \\
(2009)\end{array}$ & $\begin{array}{l}\text { In the case of the Mexican banking system, Maudos and Solís found } \\
\text { a positive relationship between the intermediation margin and variables } \\
\text { proxying market power (Lerner index), operating cost, volatility } \\
\text { of market interest rates, and implicit interest payment; and a negative } \\
\text { relationship with the quality of management and non-interest income. }\end{array}$ \\
\hline Kasman et al. (2010) & $\begin{array}{l}\text { They found that during the consolidation period (1996-2000), some } \\
\text { variables, such as operating cost ratio, Lerner index (LI), capital ratio } \\
\text { and credit risk have the most significant and positive impacts on the } \\
\text { NIM, while bank size and managerial efficiency have a negative } \\
\text { relationship with the NIM, in the case of new European Union members' } \\
\text { and candidate members' economies. }\end{array}$ \\
\hline
\end{tabular}

Source: Compiled by the author.

\section{Methodology and data}

The aim of this study is to determine the relationship between the Interest Rate Spread and selected banking markets' specific variables and macroeconomic variables by employing panel data estimation methodology. The set of independent variables employed in our study covers commonly used macroeconomic and bank-specific variables, aggregated at the level of eight countries of the SEE region (including Albania, Bosnia Herzegovina, Serbia, Croatia, Macedonia, Slovenia, Bulgaria and Romania). The research used panel data analysis with data drawn from the Central Banks' Annual Reports of the respective countries and the Financial Development and Structure Dataset-Global Financial Development Database (The World Bank). Due to a lack of availability of comparable data, this analysis is limited to the period between 2000 and 2014.

As a proxy variable for measuring variation in NIMs, IRS was employed. A dependent variable IRS is calculated by the lending rate minus the deposit rate. The independent variables in our regression models are credit risk (i.e. NPL, bank nonperforming loans, and total gross loans), bank size (logarithms of total bank assets), bank concentration (i.e. BCON, a measure of market power in the banking market by the Lerner index), bank overhead costs to total assets (OPERAT), liquidity risk (i.e. LQDR, bank liquid reserves to bank assets ratio), bank return on assets (i.e. ROA, after tax), GDP growth rate and inflation (i.e. INFL, consumer prices, annual), and bank credits to bank deposits ratio (CDR). All variables are expressed as percentage values.

The model employs balanced data including observations for all individual units in all time periods. In panel data analysis, $\mu \mathrm{i}$ is called an unobserved component, latent variable or unobserved heterogeneity. It is further discussed in terms 
of whether $\mu \mathrm{i}$ should be treated as a fixed effect or random effect. $\mu$ i is called a random effect when it is handled as a random variable. We express it as a fixed effect when it is handled as a parameter to be estimated for each cross-section observation " $i$ ", and it means that a correlation between the unobserved effect, $\mu \mathrm{i}$, and the observed explanatory variables, $\mathrm{X}$, is allowed (Wooldridge 2002).

We can define the random effects model as follows:

$$
\mathrm{IRS}_{\mathrm{it}}=\beta_{0}+\sum_{\mathrm{k}=1}^{\mathrm{K}} \beta_{\mathrm{k}} \mathrm{X}_{\mathrm{kit}}+\left(\mathrm{u}_{\mathrm{it}}+\mu_{\mathrm{i}}\right)
$$

In this model, IRSit is our dependent variable "interest rate spread" of a country " $i$ " in year " $t$ ". Xkit expresses the value of independent variables " $k$ " in year " $t$ " for country " $\mathrm{i}$ ". $\beta \mathrm{k}$ is $\mathrm{Kx} 1$ parameter vector, while $\beta 0$ is the intercept and uit is the usual disturbance term. In the random effects model, an unobserved effect is not fixed. Therefore, the model puts $\mu \mathrm{i}$ into the error term and tries to separate the effects of both error terms in the model.

The fixed effects model may be defined as follows:

$$
\mathrm{IRS}_{\mathrm{it}}=\beta_{0 \mathrm{i}}+\sum_{\mathrm{k}=1}^{\mathrm{K}} \beta_{\mathrm{k}} \mathrm{X}_{\mathrm{kit}}+\mathrm{u}_{\mathrm{it}}
$$

$\beta 0 \mathrm{i}$ means each country has its own fixed effect, and the differences among units are stated as differences in the intercepts. The biggest advantage of the fixed effects model is that it allows for the correlation between independent variables and an unobserved effect, $\mu$ i.

The period effects panel model can be defined as follows:

$$
\mathrm{IRS}_{\mathrm{it}}=\beta_{0}+\gamma_{\mathrm{t}}+\sum_{\mathrm{k}=1}^{\mathrm{K}} \beta_{\mathrm{k}} \mathrm{X}_{\mathrm{kit}}+\mathrm{u}_{\mathrm{it}}
$$

indicates a time-specific effect. In panel data analysis, we sometimes encounter one-way models that capture only time effects in the sample. The time-specific effect does not change for countries.

The following hypothesis will be tested:

H0: The hypothesis for each variable is that the selected variable has no significant impact on banks' IRS.

H1-9: The hypothesis for each variable is that the selected variable has a significant impact on banks' IRS. 


\section{Empirical findings and discussion}

Table 2 displays information related to the multicollinearity among independent variables used in the regression analysis. As shown in the correlation matrix (Table 2), there is no significant problem of multicollinearity between the independent variables. The correlation coefficients between the independent variables take on a value of -0.0072 to -0.5201 , implying a moderate degree of collinearity between the variables. The explanatory variable of LQDR has a positive correlation coefficient with the other variables with the exception of NPL and BANKSIZE. The explanatory variable of CDR has a positive correlation coefficient with NPL; BANKSIZE, BCON, OPERAT, as well as a negative correlation coefficient with LQDR, ROA and GDPGROWTH. Further, the GDPGROWTH variable also has a positive correlation coefficient with the other variables, with the exception of NPL and BANKSIZE. Unlike the aforementioned variables, ROA has a negative correlation coefficient with the majority of variables in the model (with the exception of OPERAT and LQDR).

Table 2. Correlation Matrix of Key Explanatory Variables

\begin{tabular}{|l|c|c|c|c|c|c|c|c|c|}
\cline { 2 - 11 } \multicolumn{1}{c|}{} & NPL & BANKSIZE & BCON & OPERAT & LQDR & ROA & GDP & INFL & CDR \\
\hline NPL & 1.0000 & & & & & & & & \\
\hline BANKSIZE & -0.1884 & 1.0000 & & & & & & & \\
\hline BCON & -0.1017 & -0.1139 & 1.0000 & & & & & & \\
\hline OPERAT & 0.2778 & -0.1614 & 0.1108 & 1.0000 & & & & & \\
\hline LQDR & -0.2621 & -0.5201 & 0.1208 & 0.2500 & 1.0000 & & & & \\
\hline ROA & -0.3653 & -0.0110 & -0.007 & 0.0496 & 0.3684 & 1.0000 & & & \\
\hline GDP & -0.4059 & -0.2640 & 0.1308 & 0.1264 & 0.5001 & 0.3409 & 1.0000 & & \\
\hline INFL & -0.0446 & 0.0458 & 0.0759 & 0.3643 & 0.2896 & 0.1705 & 0.1813 & 1.000 & \\
\hline CDR & 0.1964 & 0.3130 & 0.000 & 0.1643 & -0.4144 & -0.3991 & -0.2404 & 0.249 & 1.000 \\
\hline
\end{tabular}

Source: Author's calculations.

The Hausman test is employed to compare fixed effects and random effects estimators. With respect to the Hausman test, the null hypothesis that states the random effects model is the correct specification is rejected at the significance level of $1 \%$, and our findings are in favor of fixed effects model (e.g. Chi-squared statistic: 57.08, with prob. 0.000) for identifying the determinants of IRS. According to the results in Table 3, it can be concluded that the movements of certain variables are not in accordance with the basic assumption of the model. The corresponding results obtained by analysing the panel data reveal that four variables were found to be statistically significant in fixed-effects Model (2), as follows: NPL, BCON are statistically significant at 5\%, while INFL and OPERAT are statistically significant at $1 \%$.

The parameter $\beta$ has a positive sign for all years. In addition, the panel data model with fixed effects attempts to explain that, on average, the $\beta$ parameters of individual variables for all years have an impact on the rate of the IRS. The method 
of panel data with fixed effects model is employed and the connections between all independent variables have been previously tested to eliminate the potential problem of multicollinearity. According to the F-test, the model as a whole is also statistically significant (e.g. p-value: $0.0000<0.05$ ). The explanatory power of the model is moderate; about $41.30 \%$ of the volatilities in the IRS are explained by the volatilities of the independent variables (Model 2). By using the likelihood ratio test, we examined the significance of the fixed effects model and found the importance of Periodic effects (Model 3). Model 3 with dummy variables for each year has the p-value of the F-test measured at .0000 (at $1 \%$ significance level) with very low explanatory power, accounting for $19.90 \%$ of the total variance. Taking each year individually, the coefficients of the time period are not statistically significant only for 2001, 2002, 2003 and 2008.

Accordingly, a 1 percent increase in NPL in total loans, ceteris paribus, will increase interest rate spread by $0.19 \%$, and a 1 percent increase in INFL will have a positive effect on interest rate spread by $0.28 \%$. On the other hand, a 1 percent increase in Bank concentration and OPERAT will decrease interest rate spread by $0.22 \%$ and $0.218 \%$, respectively.

A simple computation shows that all other variables in our model are not significant in explaining the variance of the dependent variable, even at the $10 \%$ level (e.g. BANKSIZE, ROA, GDPGROWTH, CDR and LQDR). Moreover, according to our findings, it is obvious that slow process of the privatization and transition of these countries to a market-driven economy caused some deviations, in addition to the fact that their economic performance is influenced by variables that are not necessarily included in our models.

Table 3. Regression Results

\begin{tabular}{|l|c|c|c|c|}
\hline \multicolumn{1}{|c|}{ VARIABLES } & $\begin{array}{c}\text { MODEL 1 } \\
\text { (Pooled OLS) }\end{array}$ & $\begin{array}{c}\text { MODEL 2 } \\
(\mathbf{F E )}\end{array}$ & $\begin{array}{c}\text { MODEL 3 } \\
\text { (Period-effects) }\end{array}$ & $\begin{array}{c}\text { MODEL 4 } \\
(\mathbf{R E )}\end{array}$ \\
\hline NPL & .2770799 & .1923381 & .2436431 & .2770799 \\
\hline & {$[6.29]^{* * *}$} & {$[2.50]^{* *}$} & {$[4.40]^{* * *}$} & {$[7.49]^{* * *}$} \\
\hline BANKSIZE & 2.229687 & -4.283746 & -8.116089 & 2.229687 \\
\hline & {$[4.13] * * *$} & {$[-1.71]$} & {$[-3.59]^{* * *}$} & {$[2.62]^{* * *}$} \\
\hline BCON & -.0410685 & -.2238725 & -.2677945 & -.0410685 \\
\hline & {$[-0.22]$} & {$[-3.03]^{* *}$} & {$[-1.65]$} & {$[-0.40]$} \\
\hline OPERAT & -.1170818 & -.2189361 & -.2618203 & -.1170818 \\
\hline & {$[-1.39]$} & {$[-6.86]^{* * *}$} & {$[-2.29]^{* *}$} & {$[-1.17]$} \\
\hline LQDR & .106988 & .0431553 & .0669577 & .106988 \\
\hline & {$[6.41] * * *$} & {$[1.49]$} & {$[2.34]^{* *}$} & {$[4.90] * * *$} \\
\hline ROA & .1516598 & .3595916 & .3856324 & .1516598 \\
\hline & {$[0.56]$} & {$[1.00]$} & {$[1.34]$} & {$[0.43]$} \\
\hline GDPGROWTH & .0724137 & .0200562 & .0340044 & .0724137 \\
\hline & {$[1.04]$} & {$[0.44]$} & {$[0.36]$} & {$[0.99]$} \\
\hline
\end{tabular}




\begin{tabular}{|l|c|c|c|c|}
\hline \multicolumn{1}{|c|}{ VARIABLES } & $\begin{array}{c}\text { MODEL 1 } \\
\text { (Pooled OLS) }\end{array}$ & $\begin{array}{c}\text { MODEL 2 } \\
\text { (FE) }\end{array}$ & $\begin{array}{c}\text { MODEL 3 } \\
\text { (Period-effects) }\end{array}$ & $\begin{array}{c}\text { MODEL 4 } \\
\text { (RE) }\end{array}$ \\
\hline INFL & .340333 & .2828915 & .3078157 & .340333 \\
\hline CDR & {$[11.03]^{* * *}$} & {$[6.94]^{* * *}$} & {$[10.05]^{* * *}$} & {$[7.53] * * *$} \\
\hline & -.0064389 & .0165812 & .0226657 & -.0064389 \\
\hline C & {$[-0.98]$} & {$[1.27]$} & {$[2.50]^{* *}$} & {$[-0.56]$} \\
\hline & -9.845874 & 18.98909 & 29.72613 & -9.845874 \\
\hline Sigma_u & {$[-3.42] * * *$} & {$[1.47]$} & {$[3.45]$} & {$[-2.48]^{* *}$} \\
\hline Sigma_e & 0 & 2.9413509 & 4.509703 & 0 \\
\hline rho & 1.5512391 & 1.5512391 & 1.5229699 & 1.5512391 \\
\hline R squared & 0 & .78238677 & .89762758 & 0 \\
\hline R squared within & 0.7708 & 0.4130 & 0.1990 & 0.7708 \\
\hline $\begin{array}{l}\text { R squared } \\
\text { between }\end{array}$ & 0.8576 & 0.8004 & 0.8359 & 0.7319 \\
\hline $\begin{array}{l}\text { F test, Period } \\
\text { effects }\end{array}$ & & 0.0357 & 0.0000 & 0.8576 \\
\hline
\end{tabular}

Note: The t-statistics are shown in parentheses [], ***, ** and *, and are statistically significant at $1 \%, 5 \%$ and $10 \%$ levels, respectively.

Source: Author's own calculations

The study found the variables of credit risk and inflation to be statistically significant at $1 \%$ in explaining IRS. Our findings are in line with some studies conducted by other researchers, such as Carbó and Rodríguez (2007), Maudos and Guevara (2004), Brock and Suarez (2000) and Kasman et al. (2010).

Commercial banks have significantly slowed their lending activities, which caused a further decline in overall economic activities and a deepening of the recession. After two years of slight recovery from the global recession, in 2012, the five countries of the SEE region (i.e. Albania, B\&H, Croatia, Macedonia, and Serbia), as a group, experienced a second wave of recession.

The deterioration of business conditions, as a result of the economic crisis, caused a rise in the share of NPLs to total loans. Recently, some parent banks from abroad significantly tightened their lending policies in the host economies. High levels of NPLs mean that banks have chronic problems with writing off bad loans. It was shown that in particular during the crisis and recessions, credit risk increases, and banks compensate by increasing interest rate margins.

The negative coefficient of operational efficiency (i.e. OPERAT variable) is in contrast to previous research by Demirgüç-Kunt and Huizinga (1999) and Maudos and Guevara (2004). This can be explained by the fact that the banking sector of the SEE region is operationally inefficient; commercial banks have relatively low operating efficiency leading banks to set higher bank interest margins. This is in line with research conducted by Yener et al. (2001) and Claeys and Vander Vennet (2008), who also found a negative impact of operating efficiency on Bank Interest Margins. 
Additionally, the BANKSIZE variable (in Model 2) has a negative and statistically insignificant relationship with IRS (i.e. it is not in line with the study conducted by Kasman et al. (2010) and contradicts the earlier findings of Demirgüç-Kunt and Huizinga (1999)). Our findings confirm the perception that large foreign banks mostly have technological advantages compared to domestic banks and may be able to benefit from economies of scale and their size by maintaining narrow interest spreads.

Furthermore, we found that inflation is associated with higher interest margins at $1 \%$ statistical significance levels. Similar findings have been found by Demirgüç-Kunt and Huizinga (1999) and Boyd et al. (2009).

The positive relationship between INFL and IRS points to the fact that, in all countries of the region, it has ensured macroeconomic stability with low inflation rates (with the exception of Serbia). It seems that inflation expectations exert upwards pressure on interest rate margins prompting banks to increase their base lending rates.

It has been found that a variable of BCON measured by the Lerner index has an inverse relationship with IRS in Model 2. In contrast to much previous research, we found that a high level of banking concentration exerts a strong negative and significant impact on interest rate margins.

This is not in line with the findings of earlier studies conducted by Demirgüç-Kunt and Huizinga (1999), Carbo and Rodriguez (2007), Peshev (2015) and others. This inverse relationship between the two variables can be explained by the fact that the high level of banking concentration in the SEE region may restrain market power, reduce loan rates and decrease interest rate margins as found by Leroy and Lucotte (2016) in a sample of 54 European listed banks.

Another explanation for the high level of banking concentration in the SEE region is the fact that commercial banks represent the largest types of financial intermediaries and primary source of long-term financing, with a share of over $90 \%$ of the total assets of the financial sector while the share of non-bank financial institutions is negligible.

With reference to the criteria of concentration, SEE's banking sector measured by the Lerner index remains very concentrated although there are considerable variations across selected countries. The first group of countries, with a high level of banking concentration, comprises Albania, Macedonia and Serbia. The second group of countries, with a moderate level of banking concentration or a relatively fragmented market share, covers B\&H, Croatia, Romania, Bulgaria and Slovenia.

Variable CDR is shown to be statistically insignificant. One of the reasons for its insignificance is the fact that in all SEE countries, with the exception of Macedonia, Albania and $\mathrm{B} \& \mathrm{H}$, the ratio of loans to deposits from banks exceeded 100 percent. It shows the small domestic deposit base of the banking sector and the relatively high dependence on other types of borrowing (i.e. open credit lines and interbank lending market). Along with the above findings, the following conclusions can be drawn: (see Table 4). 
Mehmed Ganić

Table 4. Nature and Strength of the Impact of Determinants on IRS

\begin{tabular}{|l|l|l|}
\hline \multicolumn{1}{|c|}{$\begin{array}{c}\text { Explanatory } \\
\text { variable }\end{array}$} & \multicolumn{1}{|c|}{ Model $\mathbf{2}$} & \multicolumn{1}{c|}{ Model $\mathbf{3}$} \\
\hline NPL & $\begin{array}{l}\text { Positive and Significant } \\
\text { Reject } \mathbf{H}_{\mathbf{0}}: \text { yes }\end{array}$ & $\begin{array}{l}\text { Positive and Significant } \\
\text { Reject } \mathbf{H}_{\mathbf{0}}: \text { yes }\end{array}$ \\
\hline BANKSIZE & $\begin{array}{l}\text { Negative and Significant } \\
\text { Reject } \mathbf{H}_{\mathbf{0}}: \text { no }\end{array}$ & $\begin{array}{l}\text { Negative and Significant } \\
\text { Reject } \mathbf{H}_{\mathbf{0}}: \text { yes }\end{array}$ \\
\hline BCON & $\begin{array}{l}\text { Negative and Significant } \\
\text { Reject } \mathbf{H}_{\mathbf{0}}: \text { yes }\end{array}$ & $\begin{array}{l}\text { Negative and Non-significant } \\
\text { Reject } \mathbf{H}_{\mathbf{0}}: \text { no }\end{array}$ \\
\hline OPERAT & $\begin{array}{l}\text { Negative and Significant } \\
\text { Reject } \mathbf{H}_{\mathbf{0}}: \text { yes }\end{array}$ & $\begin{array}{l}\text { Negative and Significant } \\
\text { Reject } \mathbf{H}_{\mathbf{0}}: \text { yes }\end{array}$ \\
\hline LQDR & $\begin{array}{l}\text { Positive and non-significant } \\
\text { Reject } \mathbf{H}_{\mathbf{0}}: \text { no }\end{array}$ & $\begin{array}{l}\text { Positive and Significant } \\
\text { Reject } \mathbf{H}_{\mathbf{0}}: \text { yes }\end{array}$ \\
\hline ROA & $\begin{array}{l}\text { Positive and Non-significant } \\
\text { Reject } \mathbf{H}_{\mathbf{0}}: \mathbf{n o}\end{array}$ & $\begin{array}{l}\text { Positive and Non-significant } \\
\text { Reject } \mathbf{H}_{\mathbf{0}}: \mathbf{n o}\end{array}$ \\
\hline GDP & $\begin{array}{l}\text { Positive and Non-significant } \\
\text { Reject } \mathbf{H}_{\mathbf{0}}: \text { no }\end{array}$ & $\begin{array}{l}\text { Positive and Non-significant } \\
\text { Reject } \mathbf{H}_{\mathbf{0}}: \text { no }\end{array}$ \\
\hline INFL & $\begin{array}{l}\text { Positive and Significant } \\
\text { Reject } \mathbf{H}_{\mathbf{0}}: \text { yes }\end{array}$ & $\begin{array}{l}\text { Positive and Significant } \\
\text { Reject } \mathbf{H}_{\mathbf{0}}: \text { yes }\end{array}$ \\
\hline CDR & $\begin{array}{l}\text { Positive and Non-significant } \\
\text { Reject } \mathbf{H}_{\mathbf{0}}: \text { no }\end{array}$ & $\begin{array}{l}\text { Positive and Significant } \\
\text { Reject } \mathbf{H}_{\mathbf{0}}: \text { yes }\end{array}$ \\
\hline
\end{tabular}

Source: Author's own calculations.

\section{Conclusion}

This paper explored the impacts of various bank-specific and macroeconomic determinants across SEE countries on NIMs. The panel data employed fixed-effects models. The number of analyzed independent variables in our sample was selected according to findings that have been shown to be statistically significant in relevant empirical studies.

The study could not find or confirm that all the independent variables employed in the regression model have an important role in the explanation of the variance, or in the rates of NIMs. This indicates that the movements in NIMs are determined by some other factors that are relevant for countries in transition.

In line with some expectations, our findings confirm the importance of credit risk, bank concentration, operative efficiency, and inflation expectations in determining NIMs, but with some unexpected signs (e.g. bank concentration). The result also revealed that no statistically significant relationship was found between NIMs and the following explanatory variables: output growth, bank profitability, bank size and liquidity risk. These findings imply that there is no evidence to confirm that changes in economic growth and liquidity do affect changes in the structure of the NIMs. 
Moreover, some other banks' industrial policy shifts are needed to minimize related bank risks. These findings are a little different from our models' expectations and require further examination. They should be directed toward further analysis, particularly in terms of the detailed disaggregation of data on the banks' interest rate margins. Finally, it is necessary to point out that the period of analysis was relatively limited. Some of the major findings imply that the process of transition is not yet fully complete. In the end, it is important to note that the stability of the estimated parameters over a long period of time is not necessarily sustainable.

\section{References}

Agoraki, Maria-Eleni K. (2010), The determinants of net interest margin during transition. Department of Accounting and Finance, Athens University of Economics and Business, Greece.

Allen, L. (1988), The Determinants of Bank Interest Margins: A Note. 'Journal of Financial and Quantitative Analysis', 23 (2).

Angbazo, L. (1997), Commercial Bank Net Interest Margins, Default Risk, Interest-Rate Risk, and Off-Balance Sheet Banking. 'Journal of Banking and Finance', 21 (1).

Athanasoglou, P., Brissimis, S. \& Delis, M. (2005). Bank-Specific, Industry-Specific and Macroeconomic Determinants of Bank Profitability. 'Working Paper Series Bank of Greece', 25.

Bank of Albania, Annual Reports (various issues).

Banca Naţională a României, Annual Reports (various issues).

Bank of Slovenia, Annual Reports (various issues).

Boyd, J.H., Nicolo, G. \& Jalal, A.M. (2009), Bank Competition, Risk and Asset Allocations. 'IMF Working Paper', WP/09/143.

Brock, P., and L. Rojas-Suarez (2000), Understanding the Behavior of Bank Spreads in Latin America, 'Journal of Development Economics', Vol. 63 (1).

Carbó, S. V. \& Rodríguez, F.F. (2007), The Determinants of Bank Margins in European Banking. 'Journal of Banking and Finance', 31 (7).

Central Bank of Bosnia and Herzegovina, Annual Report (various issues).

Central Bank of the Republic of Bulgaria, Annual Report (various issues).

Claeys, S. \& Vander Vennet, R. (2008), Determinants of Bank Interest Margins in Central and Eastern Europe: A Comparison with the West. 'Economic Systems', 32.

Croatian National Bank, Annual Report (various issues).

Demirgüç-Kunt, A. \& Huizinga, H. (1999), Determinants of Commercial Bank Interest Margins and Profitability: Some International Evidence. 'The World Bank Economic Review', 13 (2).

Dumicic, M. \& Rizdak, T. (2013), Determinants of Banks' Net Interest Margins in Central and Eastern Europe. 'Financial Theory and Practice', 37 (1), Retrieved June 28 2016, from http://www. fintp.hr/upload/files/ftp/2013/1/dumicic_rizdak.pdf

EBRD, Transition Report, http://www.ebrd.com/, (15.07.2013). 
Entrop, O., Memmel, C., Ruprecht, B. \& Wilkens, M. (2012), Determinants of Bank Interest Margins: Impact of Maturity Transformation. 'Deutsche Bundesbank Discussion Paper', 17.

Goddard, J., Molyneux, P. \& Wilson, J. (2004), The Profitability of European Banks: A Cross-Sectional and Dynamic Panel Analysis. In: The Manchester School, 72(3).

Hawtrey, K. \& Liang, H. (2008), Bank Interest Margins in OECD Countries. 'North American Journal of Economics and Finance', 19.

Ho, T. S.Y. \& Saunders, A. (1981), The Determinants of Bank Interest Margins: Theory and Empirical Evidence. 'Journal of Financial and Quantitative Analysis', 16.

Kasman, A., Tunc, G., Vardar, G. \& Okan, B. (2010), Consolidation and Commercial Bank Net Interest Margins: Evidence from the Old and New European Union Members and Candidate Countries. 'Economic Modelling', 27.

Marinković, S. \& Radović, O. (2014), Bank Net Interest Margin Related to Risk, Ownership and Size: An Exploratory Study of the Serbian Banking Industry. 'Economic Research-Ekonomska Istraživanja', 27 (1), Retrieved January 13 2017, from http://www.tandfonline.com/doi/full/10.1080/ 1331677X.2014.952114

Maudos, J. \& Guevara, J.F. (2004), Factors Explaining the Interest Margin in the Banking Sectors of the European Union. 'Journal of Banking \& Finance', 28 (9).

Maudos, J. \& Solís, L. (2009), The Determinants of Net Interest Income in the Mexican Banking System: An Integrated Model. 'Journal of Banking and Finance', 33 (10).

McShane, R. \& Sharpe, I. (1985), A Time Series-Cross Section Analysis of the Determinants of Australian Trading Bank Loan/Deposit Interest Margins: 1962-1981. 'Journal of Banking and Finance', 9 (1).

National Bank of Serbia, National Bank of Serbia, Annual Report (various issues).

National Bank of the Republic of Macedonia, Annual Report (various issues).

Peshev, P. (2015), Determinants of Interest Rate Spreads in Bulgaria, National Bank of Bulgaria, 'Discussion Papers' Dp19912015, p. 8).

Saunders, A. \& Schumacher, L. (2000), The Determinants of Bank Interest Rate Margins: An International Study. 'Journal of International Money and Finance', 19 (6).

Schwaiger, M.S. \& Liebeg, D. (2006), Determinants of the Interest Rate Margins of Austrian Banks. Financial Stability Report of Austrian Central Bank, 12.

Tang, H., Zoli, E. \& Klytchmkova, I. (2000), Banking Crises in Transition Economies- Fiscal Costs and Related Issues. 'Policy Research Working Paper', 2484, The World Bank, Washington.

Tennant, D. \& Folawewo, A. (2012), Macroeconomic and Market Determinants of Banking Sector Interest Rate Spread: Empirical Evidence from Low and Middle Income Countries. 'Modern Economy', 3 (7).

Ugur, A. \& E. Hakan (2010). Determinants of the Net Interest Margins of Banks in Turkey, 'Journal of Economic and Social Research', 12 (2) 2010, pp. 101-118.

Wooldridge, Jeffrey M. (2002), Econometric Analysis of Cross Section and Panel Data, London, The MIT Press.

The World Bank, (2013), The Global Financial Development Database.

Yener, A., Evans, L. and Molyneux, P. (2001), Bank Ownership and Efficiency Journal of Money, Credit and Banking, 33(4), 925-954. 


\section{APPENDIX}

Appendix 1. Description of variables

\begin{tabular}{|l|l|l|}
\hline \multicolumn{1}{|c|}{ Notation: } & \multicolumn{1}{|c|}{ Variable description: } & \multicolumn{1}{c|}{ Source: } \\
\hline IRS & $\begin{array}{l}\text { Interest rate spread (IRS) as proxy for Net Interest } \\
\text { Margin (NIM) is used for bank i in period t } \\
\text { computed as the difference between lending rate } \\
\text { and deposit rate }\end{array}$ & $\begin{array}{l}\text { Global Financial } \\
\text { Development Database }\end{array}$ \\
\hline \multicolumn{2}{|c|}{ Explanatory variables } \\
\hline $\begin{array}{l}\text { NPL/ Credit } \\
\text { risk }\end{array}$ & $\begin{array}{l}\text { Credit risk is measured by bank nonperforming } \\
\text { loans total gross loans }\end{array}$ & $\begin{array}{l}\text { Global Financial } \\
\text { Development Database }\end{array}$ \\
\hline $\begin{array}{l}\text { SIZE/ Market } \\
\text { share/ Market } \\
\text { power }\end{array}$ & $\begin{array}{l}\text { Bank size is measured as the log of bank's total } \\
\text { assets }\end{array}$ & NCB's annual reports \\
\hline $\begin{array}{l}\text { BCON/ Market } \\
\text { concentration }\end{array}$ & Market concentration is measured by Lerner index & $\begin{array}{l}\text { Global Financial } \\
\text { Development Database }\end{array}$ \\
\hline $\begin{array}{l}\text { OPERAT/ } \\
\text { Operational } \\
\text { efficiency }\end{array}$ & $\begin{array}{l}\text { Operating efficiency is computed as the ratio } \\
\text { of bank overhead costs to total assets }\end{array}$ & $\begin{array}{l}\text { Global Financial } \\
\text { Development Database }\end{array}$ \\
\hline $\begin{array}{l}\text { LQDR/ } \\
\text { Liquidity risk }\end{array}$ & $\begin{array}{l}\text { Liquidity risk is computed as the ratio of bank's } \\
\text { liquid assets to total assets }\end{array}$ & $\begin{array}{l}\text { Global Financial } \\
\text { Development Database }\end{array}$ \\
\hline $\begin{array}{l}\text { ROA/ } \\
\text { Profitability }\end{array}$ & $\begin{array}{l}\text { Profitability expressed as bank return on assets } \\
\text { (ROA, after tax), }\end{array}$ & $\begin{array}{l}\text { Global Financial } \\
\text { Development Database }\end{array}$ \\
\hline CDR & Bank credits to bank deposits ratio & $\begin{array}{l}\text { Global Financial } \\
\text { Development Database }\end{array}$ \\
\hline $\begin{array}{l}\text { GDP-output } \\
\text { growth }\end{array}$ & Growth rate of real GDP. & WDI World Bank \\
\hline INFL & Inflation (consumer prices, annual). & WDI World Bank \\
\hline
\end{tabular}




\section{Appendix 2. Hausman Test}

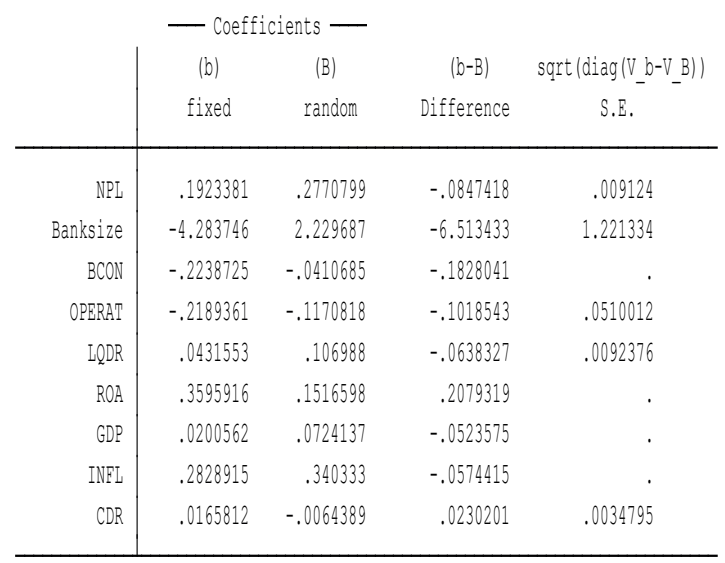

$b=$ consistent under Ho and Ha; obtained from xtreg $\mathrm{B}=$ inconsistent under $\mathrm{Ha}$, efficient under $\mathrm{Ho}$; obtained from xtreg

Test: Ho: difference in coefficients not systematic

$$
\begin{aligned}
\operatorname{chi2}(9) & =(b-B)^{\prime}\left[\left(V_{-} b-V_{-} B\right)^{\wedge}(-1)\right](b-B) \\
& =57.08 \\
\text { Prob>chi2 } & =0.0000 \\
\left(V_{-} b-V_{-} B\right. & \text { is not positive definite })
\end{aligned}
$$

\section{Appendix 3. Heteroskedasticity Test}

Modified Wald test for groupwise heteroskedasticity

in fixed effect regression model

HO: $\operatorname{sigma}(i)^{\wedge} 2=\operatorname{sigma}^{\wedge} 2$ for all $i$

$\operatorname{chi2}(8)=54.79$

Prob>chi2 $=\quad 0.0000$ 


\section{Appendix 4. Autocorrelation Test}

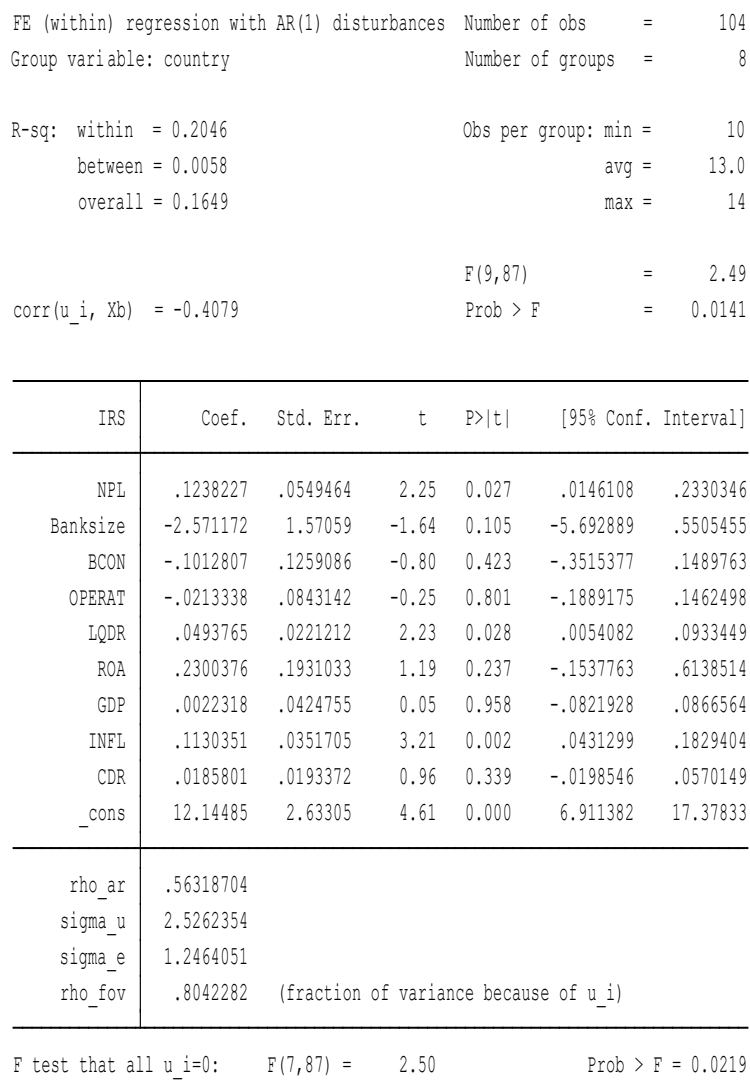




\title{
Streszczenie
}

\section{ANALIZA EMPIRYCZNA CZYNNIKÓW WPLYWAJĄCYCH NA WYSOKOŚĆ BANKOWEJ MARŻY ODESTKOWEJ: DANE Z KRAJÓW EUROPY POLUDNIOWO-WSCHODNIEJ}

\begin{abstract}
Niniejszy artykuł przedstawia analizę empiryczną czynników wpływających na wysokość bankowej marży odsetkowej w ośmiu krajach Europy Poludniowo-Wschodniej (SEE) w latach 2000-2014. Celem artykułu jest zbadanie głównych przyczyn zmian marży odsetkowej $w$ wybranych krajach wymienionego regionu. Ponadto, w opracowaniu zbadano relacje pomiędzy zmienna zależna - rozpiętościa stóp procentowych (IRS - jako zmienna zastępcza analizy zmian rozpiętości marży odsetkowej) oraz zbiorem wybranych szczegółowych zmiennych w krajach Europy Południowo-Wschodniej z zastosowaniem metody przewidywania danych panelowych. Badanie to jest wykonane na podstawie zbiorczych danych dla catego sektora bankowego $w$ wymienionych krajach. Zgodnie z założeniami, rezultat badań wskazał znaczenie ryzyka kredytowego, koncentracji banków, efektywności operatywnej i prognoz inflacji w wyznaczaniu wysokości marży odsetkowej. Co istotne, w przeciwieństwie do większości dotychczasowych badań empirycznych, stwierdzono odwrotna zależność pomiędzy zmienna koncentracji banków $i$ wysokościa marży odsetkowej, podobnie jak w przypadku efektywności operatywnej. Ponadto, $w$ opisanym badaniu nie znaleziono statystycznie wystarczalnych dowodów iż marża odsetkowa jest determinowana przez wzrost gospodarczy, rentowność banku (mierzona przez ROA) oraz ryzyko ptynności.
\end{abstract}

Slowa kluczowe: determinanty bankowe, determinanty makroekonomiczne, rozpiętość marży odsetkowej, region Europy Poludniowo-Wschodniej (SEE) 